NCBI Bookshelf. A service of the National Library of Medicine, National Institutes of Health.

Reinisch J. The Perils of Peace: The Public Health Crisis in Occupied Germany. Oxford (UK): OUP Oxford; 2013 Jun 6.

\title{
Chapter 6 Public Health Work in the American Occupation Zone
}

Plans

Many features of the American approach to the occupation resembled those of the British. They had jointly prepared within the SHAEF organization, and so had similar general orientations, and public health was a subject on which American and British plans were particularly closely coordinated. In January 1945, Colonel William L.Wilson, deputy director of SHAEF's G5 Division (and later deputy chief of the American Public Health Branch in Germany), reminded his staff of the 'impossibility of separating American and British public health operations into strict national areas', and asked them to ensure close coordination. ${ }^{1}$ SHAEF's Public Health Branch was led by Major General Warren F. Draper (drafted from the United States Public Health Service), and his deputies, the American Colonel Wilson and the British Brigadier Thomas F. Kennedy. ${ }^{2}$ Initial American assumptions were similar to those we encountered in Chapter 5: they, too, insisted that Allied input into German reconstruction was to be strictly limited and no imports were to be made available; that any work was to 'be based upon a program whereby the Germans are made responsible for providing for themselves, out of their own work and resources'. ${ }^{3}$ American guidelines also spelled out, just as the British had done, that existing German administrations were to be taken over and supervised indirectly, and health officers were instructed to supervise the German health system while also denazifying it. ${ }^{4}$ In September 1944, General Eisenhower's proclamation No. 1 to the German people stated that the Americans intended to take over and revive the existing administrative machinery, and ordered all German officials to remain in place and continue to work. 5

Until 14 July 1945, when SHAEF was dissolved, the British and Americans shared and combined their plans for German occupation and military government. Thereafter the Allied forces were broken up into their national elements, and Eisenhower became commander only for the American troops. He was in charge of USFET (United States Forces, European Theater), and from March 1947 of EUCOM (United States, European Command).

'Separation meant', Eisenhower explained, 'that we had to sort out all our complicated and highly integrated staffs, organisations, and procedures in order to meet the new requirements of national administration and responsibility. ${ }^{6}$ From this, some notable differences between the British and Americans began to emerge. Most important for the early occupation period was that denazification in the American zone was both more ambitious in scope and less flexible in operation than that attempted elsewhere. The USFET directive of 7 July 1945 stated that everyone in a position of public responsibility had to be vetted through a questionnaire (the infamous Fragebogen) on their past, which would lead to a classification into one of five categories: ${ }^{7}$ the removal of those in the first group from their positions was mandatory; the removal of those in the second and third groups was discretionary and rested with the military government officer responsible; the fourth group either faced 'no objection' to their employment or simply a lack of evidence to the contrary. Only for the fifth group would employment be recommended.

As a rule of thumb, mandatory removal would be warranted for anyone who joined the NSDAP before 1 May 1937a considerable number. In September 1945-some time after a relaxation of denazification regulations had begun in the British zone - an American directive extended this procedure into the previously unaffected fields of industry and economy. The scope of the denazification grew even wider as American investigators uncovered further evidence on the involvement of doctors in medical war crimes. In May 1945, the Civil Affairs Guide on Denazification of the German Medical Profession (partly compiled by the American Jewish medical historian George Rosen), estimated that roughly half of all German doctors were 'proven Nazis'. The worst offenders were to be identified and brought to trial as soon as possible, the guide stated, but those trials should not absolve or remove suspicion from the rest of the medical profession. All German physicians would have to undergo a thorough denazification programme. Allied officers, the guide stated, would have to assess 'the degree of culpability of the individual physician or member of the auxiliary medical profession'.

However, these formulations lacked definitions and specific guidelines. The denazification adviser to the Office of Military Government for Bavaria noted in 1950 that '[1]ike the rest of military government, denazification planning suffered from Washington indecision, Morgenthau plan influence, and Roosevelt's decision not to plan at all, ${ }^{9}$ The Americans, just like the British, lacked a detailed policy for dealing not just with the perpetrators of medical crimes, but also with the much larger number of those who had supported the Nazi regime. The problem was not simply that 
military government officers were "temperamentally interested in "getting things done", not in tearing down —and standing by', as required by the occupation policy set out in JCS $1067 / 5,{ }_{10}$-but that this document itself contained contradictions and blank spots. The denazification clauses in JCS 1067 called for the removal of those who had been more than 'nominal Nazis', but provided no formal definition of what this category involved, or explanation of how, and according to what criteria, allocation into the five categories was to proceed. There was a similar absence of instructions on which candidates would be suitable to work for the new authorities, and who could be trusted to work with, and for, the Americans, in the interim. There were more naturalized German émigrés among the American than the British troops, but most of them did not end up working for the budding German administrations. Rather, they tended to go to Germany as US citizens, and left again once their military service had come to an end. ${ }^{11}$

The American approach to denazification was shaped by a paradox not shared by the other occupiers. On one hand, Americans, too, shared a psychological understanding of Nazism, and had begun to explain fascism as a psychological or psychiatric condition. The prominent and well-funded Berkeley project on the psychology of antiSemitism, for example, had turned the concept of an 'authoritarian personality' into a popular explanatory device for the causes and consequences of Nazism. ${ }^{12}$ The conference on 'Germany after the war', held at Columbia University in spring 1944 after an initiative by the Joint Committee on Post-War Planning, built on the Berkeley project's findings to analyse the German character and its possibilities for re-education. It was attended by a number of government advisers and future military government staff. ${ }^{13}$ Once in Germany, the American authorities presumably had some contact with the German Personnel Research Branch (GPRB) discussed in the Chapter 5. The GPRB's first project in the Ministerial Collecting Centre near Kassel lay in the territory of the American zone. Individuals active within the GPRB included men such as Geoffrey Gorer, long-time resident in the United States and adviser to the American government. ${ }^{14}$ Many American occupation officials, like their British counterparts, had been exposed to this kind of analysis.

But from the start, these prevalent psychological diagnoses of Nazism were partly undermined, ultimately perhaps even cancelled out, by the fact that the American authorities were much more outspoken than the British about a second conclusion: the occupation had to be used to spread American, or 'Western', values and ideas about democracy. The Psychological Warfare Division (PWD) of SHAEF spent most of its time devising ways to popularize democratic ideals and institutions in Germay, rather than on the removal of unsuitable Germans. Lucius Clay, Eisenhower's deputy and head of the zone's policy-making body, the United States Group Control Council (USGCC), remembered in his memoirs that books, magazines, radio, cinema, theatre, and music were all soon enlisted to convince the German population about the attraction of American-style 'freedom' and 'federal democracy', and, ultimately, the 'American way of life'. In this context, rigid psychological schemes about the German mentality were of little use, Clay insisted: 'We had much advice from those who professed to know the so-called German mind,' he wrote. 'If it did exist, we never found it; German minds seemed to us to be remarkably like those elsewhere.' 15

'Unfortunately for all concerned', Carl J. Friedrich (a US occupation officer and professor of political science at Harvard of German origin) wrote in 1950, "the term "democratisation" had divergent connotations for the Western Allies and the Soviet Union. Agreements, such as the Potsdam Agreement of 1945, embodying this phrase "democratisation", were therefore in reality no more than compromises in terms of a formula.' Even the Western Allies disagreed about the nature and implications of a future German democracy. As Friedrich observed, 'each democratic nation inclines to identify the concept of democracy with its own outlook. Hence, throughout this period, the free market economy, the compatibility of socialism with a free society, the position of the civil service, and similar issues have been focal points of controversy. ${ }^{16}$ And yet the democratization agenda soon became most central to the American occupation, and eventually helped to override some of the problems which weighed down British officials. Even though a clash between a strict interpretation of denazification criteria and an insistence on the democratization purpose of the American occupation hampered the work of the American authorities, compromises eventually smoothed the path. How was this possible?

\section{Compromises}

When American troops entered German territory in the autumn of 1944, their initial reactions were similar to those of the British. The destruction in their zone was not as extreme as that confronted by many British units, but here, too, civilian life was severely disrupted, particularly in cities and larger towns. Administrative confusion was exacerbated by the zonal boundary with the French territory in the west, only finalized after endless diplomatic and military wranglings, which cut through existing infrastructures and administrative units. Many American commanders soon 
realized that even merely proceeding within their limited instructions concerning the "prevention of starvation or widespread disease or such civil unrest as would endanger the occupying forces', would demand a more far-reaching involvement by military government than they had anticipated or prepared for. ${ }^{17}$

In many areas army officials began to collaborate with local Germans. ${ }^{18}$ Here, too, relations with the Germans were coloured by the expectations and experiences detachments brought with them. Some officers in Bavaria were dismayed to find that their area had escaped damage, even though, as George Orwell and others noted, the 'Nazi movement actually started in this part of Germany, and there can be no question about the enormity of the crimes it has committed'. American generals, like the British, believed that although Prussia was the seat of German militarism, Bavaria had nourished Prussian ambitions, and, unlike Prussia, it seemed to have escaped punishment. ${ }^{19}$

US troops liberated Dachau, a concentration camp near Munich, in April 1945. Like other Allied troops who had participated in the liberation of concentration camps, those who had been there tended to judge the local population in the light of the sights, sounds, and smells of extermination and decay they had experienced, while those who had not found relations with the Germans much more straightforward and cordial. The British war correspondent Tom Pocock, who visited Belsen concentration camp shortly after its liberation, thought that 'the liberators, the victors and indeed, all who had been involved with the opening of the concentration camps had, to some degree, been infected by them and it was not with typhus'. ${ }^{20}$ American soldiers were just as marred by this infection as the British, Soviets, and French.

But such sentiments were often neutralized, not just by many GIs' fundamental lack of interest in politics and history, but also by a growing sense of sympathy for and familiarity with the defeated. General George S. Patton, always a loose cannon, was widely quoted for saying that ' $[t]$ his whole Nazi thing is just like a Democrat-Republican election fight', much to the outrage of the American press. ${ }^{21}$ But similar responses came from others. William Robertson, an American army doctor, remembered that '[w]e didn't like the German troops, but we didn't particularly dislike the German civilian population. They were quite obviously suffering. ${ }^{22}$ Leon Standifer, a young GI stationed in Germany, later wrote that ' $[\mathrm{t}]$ hose SS kids weren't very bright and had been taught some strange racial ideas, but they were ordinary boys. I was finding that I liked the German people more than I had the French or English ... I blamed Hitler and the Nazi Party for massive atrocities, but they were dead or in prison. ${ }^{23}$ Shocked by the destruction and misery, many Americans also began to discover similarities and compatibilities between American and German culture. Even if any ethnic consciousness among the heterogeneous German-Americans had been on the wane, ${ }^{24}$ German-born migrants and their descendants were, as late as 1950, more numerous than any other group of first- and second-generation Americans. ${ }^{25}$ This is one reason why many American soldiers seemed to relate so quickly and easily to the ex-enemy population: culturally, socially, and ethnically they did not seem very different from the folks at home. Even their supreme commander, Dwight D. Eisenhower, was of German Mennonite stock. ${ }^{26}$ In the light of Americans' rediscovery of familial and cultural ties to Germany, any real distinction between Germans (good or bad) and the Americans thus became increasingly difficult to articulate and uphold in practice.

This blossoming sympathy with the German plight was accompanied by the familiar problems of military discipline, and a move away from Washington's prescribed guidelines and priorities. Apart from 'souvenir hunting' and a thriving black market, it was soldiers' disregard of the fraternization ban which initially caused the greatest headaches. ${ }^{27}$ As one American put it a few years after his return from Germany: 'Here were the people who had once been renowned for their Goethe and their Schiller; now they offered to the world Dachau and Buchenwald. Their kitchens were still spotless, and the brown bread smelled delicious to soldiers tired of government issue white bread; their crematories were also spotless, and the barrels of human ashes stunned men who had seen death a hundred times on the battlefield. ${ }^{28}$ But if those soldiers who had seen the death camps saw non-fraternization as a reasonable policy, many of those who had not, together with growing numbers of American visitors to Germany, questioned the logic of the policy. 'Non-fraternization' included a range of prohibited forms of contact, such as shaking hands or eating and drinking with Germans, giving or receiving gifts, playing games or sports, sharing accommodation, as well as any form of sexual relations. ${ }^{29}$ Earlier assumptions about the need for the rule- that it would protect Allied troops from German attempts to indoctrinate them with Nazi propaganda, and that it would demonstrate to the Germans the irreversibility of their defeat ${ }^{30}$ - just did not seem to apply any longer.

At a press conference in the American zone in May 1945, one participant criticized the lack of a distinction between different kinds of Germans which was at the heart of the ban. 'Is there going to be any modification made in the nonfraternisation policy?', he asked. 'What I mean is, is there going to be any distinction drawn between Germans who were keeping people in Concentration Camps and Germans in Concentration Camps?' Clay did not have a good 
answer. He admitted that the ban had not been modified to date, nor did he know of any plans to change or abandon it. The non-fraternization rule, he said, related to 'the question of [the] regeneration of the German people' and a decision about when Americans would be 'ready to accept any part of them on any other basis than of a conquered country, which will be treated as it has earned the right to be treated'. The answer was clearly: not yet. ${ }^{31}$ A month later, Parker Buhrman from the zone's Political Division similarly questioned the policy. He pointed out that it 'would seem to contain some serious misconceptions, particularly ... relating to the "gulf between occupying armies and the Germans"', and it was 'certainly wanting in judicious objectiveness': 'If ever the present physical evidence of destruction, the destruction of the German armies, the loss of private property and resources, economic hardship and the specter of starvation does not convince the Germans of defeat,' Buhrman added, it was 'not likely that the emphasis on the "separation gulf" and "non-fraternisation" will do so.' Moreover, there was

no sound basis in human conduct or experience that would justify this policy. It risks turning the defeatism, frustration and possible hatred of their false leaders and government against us and is the best foundation upon which under-cover activities and rabble-rousers can build. If we are afraid to or unable to associate with these people in the normal, formal, practical, common sense way in the accomplishment of our mission, which is primarily to govern in a manner which leads to the establishment of a cooperative democratic state, the fault would seem to lie in us and the mission will in all likelihood be a failure. ${ }^{32}$

There were also dissenting voices. The purpose of the non-fraternization rule was to prevent soldiers from getting too close to the defeated, and a number of Americans noted with concern that breaking it had had precisely the anticipated effects. Other OMGUS officials thought that even if the policy was eventually discarded, it had been necessary and useful at the start of the occupation. Robert Murphy argued that it had at least 'served the useful purpose of bringing home to many Germans something of which I do not believe they were really conscious, notwithstanding the devastation of their country and their personal sufferings. That is the state of world opinion regarding them.' 33 But just a few months into the occupation this analysis became increasingly unpopular. Buhrman's colleague, Colonel Carter, insisted that fraternization was 'so intimately bound up with the full conduct of our Military Government in the Zone, and will so largely determine the "tone" of US Military Government, that we should re-examine our whole position in the matter in the light of Military Government objectives and necessities'. ${ }^{34}$ Many officers thought that it was just not 'common sense' to prevent Americans from having social contacts with local Germans, and, at any rate, Germans were impossible to avoid.

Health officers were among the first to warn about the ban on fraternization. Even before occupation began, they voiced concerns that it would seriously affect the control of venereal diseases among Allied troops. A soldier's infection with VD was unquestionable evidence of his 'fraternization' with German women, and fears of punishment would mean infected soldiers would not seek treatment and further exacerbate the spread of VD. ${ }^{35}$ 'It is known beyond doubt to all who are engaged in this work, whether in the medical, sociological or administrative field,' Boucher explained at a joint meeting, 'that there is no prospect whatsoever of achieving success in the battle against V.D. through the seemingly easy course of automatically making sexual intercourse by V.D. sufferers, or the transmission of the disease, a criminal offence.' 'Indeed it is highly probable', he went on, 'that it [such a policy] has tended to produce the very evil which frustrates all workers in this field-viz, that of driving the disease underground. '36 Since the Health Branch's 'main object' was 'to induce people to come forward for treatment', they objected to 'any sufferer being deterred from coming forward by the thought that disclosure of the disease will disclose an offence'. 37

This health argument effectively undermined the fraternization ban even before political arguments about the value of American soldiers' contacts with the German population first came to be heard. It was strengthened by the availability of penicillin, which made the treatment of venereal diseases faster and more efficient. Under pressure from health officers, in June 1945 an order from Eisenhower conceded that 'disciplinary and punitive measures' would not be taken for the contraction of venereal diseases ('except in instances of wilful concealment of infection'), and that contraction of VD would 'not be used, directly or indirectly, as evidence of fraternisation or as evidence of violation by the individual on non-fraternisation with the inhabitants of Germany'. ${ }^{38}$ In July 1945, German children were exempted from the ban, and in October the policy was officially, if quietly, abandoned. ${ }^{39}$ As a result of the combined effects of pressure from the health officers, the availability of penicillin, and the growing fallout between the former wartime allies, fraternization between Americans and Germans 'was no longer framed primarily as a threat to the health of Allied troops but as a welcome solidification of Cold War alliances' . 40 
As American relations with the local populations flourished in many areas, their contacts with non-German Displaced Persons (DPs) proved less tranquil and helped to cement the new bonds between Americans and Germans. DPs were disliked by occupation officials and locals alike, both because their presence exacerbated chaotic conditions and because they appeared to receive comparatively disproportionate international support. Occupation staffs begrudged DPs as a burden, especially since they felt that UNRRA, the international body responsible for their care, was unwilling or unable to pull its weight. ${ }^{41}$ Even if this criticism of UNRRA overlooked the fact that the organization's remits dictated close cooperation with military authorities in occupied areas, American officers' relations with UNRRA officials and DPs were fraught. ${ }^{42}$ Leon Standifer remembered how one of his sergeants spoke about them: 'They're getting plenty of food, the same rations as you, but keep stealing. Every bunk in the barracks has a box of stale bread and rotting food that they're saving in case the supply runs out. These people are like animals! ${ }^{43}$ DPs were blamed for increases in petty crime, venereal diseases, and general unrest. An American military government report from October 1945 stated that during September ' $[t]$ he chief source of unrest and lawlessness continued to be found in the large mass of displaced persons', and that, by contrast, 'the German population in the U.S. Zone continued to be generally orderly, and crime rates were low'. ${ }^{44}$ OMGUS health officials felt that German civilians were living on 'starvation rations', while DPs were apparently getting overweight from the food parcels and welfare packages sent to them from abroad. ${ }^{45}$ In the American zone, just as in the British, German civilians made rather good first impressions, at least compared to other groups.

That made the job of public health officers much easier. To them, non-fraternization was all the more contradictory since their plans had specified that German administrators were to carry out the bulk of necessary tasks. Like their colleagues in the other occupation zones, the American military government had neither sufficient personnel nor experience to take over the collapsed German administrations themselves, and were compelled to find and appoint German executives. At first glance, the appointment of German health officials was less urgent than in the British zone. The initial staff allocation to the US zone's Health Branch was much more generous than the British, and it even increased in the first months: in August 1945136 military government medical personnel were working in the American zone on German health matters. ${ }^{46}$ In September this increased to $145,{ }^{47}$ and in October it rose further to $170 . \underline{4}$

But although the allocation of health personnel was more generous, personnel pressures soon turned into a similar problem to that in the British zone. Plans had provided for the rapid redeployment of American troops to the war in the East, and then, after VJ Day, back to the United States. The October 1945 health report stated that around half of all military medical personnel were to be released by 1 January 1946, and their responsibilities to be taken over by US civilians and appointed Germans. 'Under the deployment program,' it stated, ' 65 of the 145 personnel now on duty could return to the United States by 1 January 1946 and 105 by 1 April $1946 .{ }^{49}$ A temporary delay to the deployment of 'certain essential individuals' among the medical officers was granted in December 1945, but only until early April 1946, when all redeployments were to be completed 'unless they specifically expressed their willingness to remain in Germany, 50

Because demobilization was scheduled to take place earlier and faster than in the British zone, it became urgent to ensure that sufficient Germans were available to take control of public health operations. The British problems stemmed from an inadequately sized Health Branch at the outset, whereas American difficulties reflected the hasty disbandment of existing personnel, but the results were similar. Of 165 military government medical personnel in the American zone on 31 July 1945, only 77 remained three months later. By November 1945, two out of the three

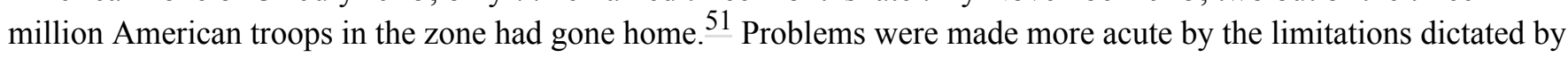
the denazification regulations on which Germans could be appointed. In the American zone, just as in the British, medical officers' petitions to relax denazification criteria, and make use of even politically suspect German doctors, proved particularly effective and successful.

In the American zone, too, an initial vehicle for highlighting the importance of 'public health' (with the prioritization of money and personnel this entailed) was a campaign to recognize the dangers of the coming winter months and to mobilize all possible resources to prevent a crisis. Health officers had their own interests in emphasizing the reality of health crises and the importance of public health, but everyone agreed on the need for more supplies, money, and personnel. At a press conference in August 1945, Eisenhower explained that the most urgent question was 'this winter and what are we going to do about it. Naturally it was not the concept of a Government to annihilate Germany. We have to keep them this winter in order to do anything about rehabilitating them later and to this end they must be fed, and all of our staffs of all units are struggling in various ways with the problems of fuel, housing and feeding.' 
Deflecting criticism from concerned taxpayers at home, he added: ' $[\mathrm{b}] \mathrm{y}$ feeding I do not mean any fancy menus. I mean merely on the existence level, and that is all I do mean.' For that to happen, more supplies would have to be brought into the zone. 'That does not mean I am going to get them fat, but it is inescapable that they must be fed this winter. 52

While a demand for more resources united all departments, health teams were able to move to the front of the queue by showing that their problems - above all the spread of infectious diseases, but also the inadequate living conditions which facilitated their proliferation-demanded urgent attention. In August 1945, the monthly health report for the American zone noted that extensive damages to utilities, water supply, sewage disposal, and housing had led to 'disrupted living conditions' that caused 'many small epidemics of dysentery, typhoid and typhus fever'. ${ }^{53}$ It urged that immediate preparations be made in order to prevent worse to come. Undamaged hospitals were overflowing with patients, and many operated in damaged buildings, and without electricity, water supply, or fuel to get them through the winter. Although it was 'imperative that repairs be made as rapidly as possible in order to increase the number of hospital beds and to conserve fuel', health officers complained, both 'necessary building materials and labor' were unavailable. 'With lack of fuel, shelter, and food, and the crowding that exists,' the report went on, 'illness and the danger of epidemics will increase the problem with the onset of cold weather.' There was only one solution: resources would have to be made available immediately to prevent an epidemic crisis during the winter months - potentially threatening the whole world. ${ }^{54}$ Such a prospect was surely too dire to be ignored by Washington.

The health teams' call to mobilize for the winter involved not only material resources and American imports, but also the ever-important demands for personnel, both the numbers of available staff and their qualifications, salaries, and professional status. This required the freedom to disregard the denazification rules. American health officers, like their British counterparts, soon insisted that any strict interpretation of the denazification regulations prevented them from appointing Germans to the most important health operations and building a functioning health service, and so harmed occupation objectives.

Months into occupation it was still not clear whether officers were to be allowed to bend the rules. In October 1945, the monthly denazification report for the American zone acknowledged that, '[i]n view of the great number of individual cases involved', it had become vital 'to establish some rapid means of determining whether former members of the Nazi Party were more than nominal participants in Party activity'. But the old rules remained in force. 'As a rough guide,' the report explained, 'those who joined the Party before 1 May 1937 are considered mandatory removal cases, while those who joined later are given a further investigation.' This procedure had been criticized for its inflexibility and lack of discrimination, the report observed, and it had necessarily resulted in the unfair treatment of some individuals. Nonetheless, it went on, 'most of the Germans who deny their complicity in Nazi Party activity' were 'undoubtedly ... merely attempting to obscure the facts and evade responsibilities for their actions'. After all, 'our policy of mass dismissal is not designed to please the German public. It has as its purpose the prompt removal of Nazi influence from public life. By virtue of its mandatory provision, some unjust arrests and removals are certain. Nevertheless, these can be corrected by individual review at a later date when our main purposes have been accomplished. ${ }^{55}$ Although the exact dates of party membership which mandated suspicion might be up for discussion, the classification of individuals into prescriptive categories persisted, and - health officers arguedseverely restricted any 'pragmatic' room to manoeuvre.

Initially, even when it came to public health, it appeared that the restrictions were going to be strictly enforced. The August 1945 health report stated that the internment camp in Kassel alone held forty-six former officials from the German Health Department, and the number was rising with each new wave of arrests. ${ }^{56}$ An USFET directive from October 1945 confirmed health officers' fears, saying that in the search for Germans 'who might be suitable for employment in Public Health operations in administrative or teaching positions', no leniency could be tolerated. 'No names should be submitted', this directive stated, 'for individuals who came into discretionary removal, mandatory removal or arrest categories under present policy directed against Nazis, militarists or persons who held high public office under the Nazi regime.' In addition to fulfilling the political criterion, candidates should also 'possess the following qualifications: a. Administrative ability and leadership qualities of a high order. b. Professional qualifications of a high order. c. Physical and mental qualifications which would fit the individual into a responsible and difficult reconstructive task'. Overall, 'great care must be exercised in nominating these persons' ${ }^{57}$

The Americans soon acquired the reputation of being the occupier who took denazification most seriously. A number of high-profile cases seemed to confirm this perception. American officials were behind the dismissal of people such as Ferdinand Sauerbruch and Franz Redeker from the Berlin Magistrat, while the other occupiers were content to let 
them remain. Despite this, there were American medical officers who argued vocally and influentially that strict denazification was not in the interest of public health and welfare, as well as impractical and impossible to carry out. In early July 1945, one official noted that thirteen of the German doctors he had appointed had been found to be politically unacceptable, but that they had to remain in office 'because suitable replacements are lacking'; there was no point in pretending otherwise. ${ }^{58}$ The August health report argued that since Nazi membership had been compulsory for holding public office, the denazification ambitions were entirely unfeasible, at least for doctors, since 'all but a few Amtsärzte (local official physicians) were Reich employees', and 'nearly all physicians were compelled to be members of the NS Ärztebund'. According to initial estimates, over 90 per cent of Bavarian veterinary officials would have to be discharged. Given the scale of the problem, 'the replacement of the incumbent Amtsarzt by a politically acceptable and technically capable physician' would 'require a long and thorough search for personnel'. 59

A month later, the health report stated that while some formerly active Nazis had been dismissed, and some replacements had been found, 'many replacements have been found to be inexperienced or too old and inactive'. Over half of the German health staffs appointed by the American military government had not been vetted, the report observed, and those who had been assessed and found unacceptable still remained 'due to operational necessity'. After all, '[m]aintenance of health is essential even if denazification is less rapid than desired'. The report went on to say that it was 'possible that much of the present typhoid incidence in Bavaria is due to the appointment of inexperienced Amtsärzte and other public health officials to replace experienced officials who were dismissed for political reasons'. ${ }^{60}$ A month later, in October 1945, frustrations were growing. 'Obtaining denazification without impairment of health operations continues to be a tedious and hazardous function', and the most arduous obstacles included the 'suitable interpretation of nominal categories, times at which their removals are mandatory, obtaining acceptable and qualified replacements and disposition of those removed' 61

Calls for a relaxation of denazification came from medical officers (both German and American) in all parts of the zone. As one appeal stated, compromises were ' $[\mathrm{u}]$ rgently needed in the interest of the medical care for the civilian population'. ${ }^{62}$ A German doctors' organization argued that, after a review of the questionnaires from the doctors practising in their area, it was clear that the American proposal to exclude all those physicians from practice who had joined the NSDAP before 1937 would be disastrous. 'The execution of the planned measure would be the end of the medical providing [sic] for the population,' it argued, 'as substitutes, ready for use, are not sufficiently available. ${ }^{63}$ Other German doctors complained that the lack of physicians hampered the operations of hospitals, and pointed to the 'anticipated hateful reaction of the population when the sick suffer or perish unattended because a doctor, although only a passive Party-member, has been dismissed'. 64

The American Public Health Branch tended to agree. 'If actual hazard to health is involved', one official wrote, it was necessary that 'non-medical Military Government Officers be prevented from indiscriminate removals of the nominal categories until suitable replacements can be found and placed on duty'. ${ }^{65}$ In December 1945, General Stayer explained in a letter to the Denazification Policy Board that it was 'imperative that adequate staffs with experienced chiefs of services be maintained in hospitals, that public health offices be occupied by well trained physicians, and that there be an adequate number of capable doctors to care for the people. Otherwise there will be increased sickness, more hospital beds will be required, and these will be occupied for unnecessarily longer periods'. The rules themselves were impractical and unjust, he insisted: 'Reliable anti-nazi [sic] physicians have stated that under the Nazi regime it was impossible to obtain appointment to or promotion in a medical school or hospital without first joining the party and that, as presently applied, the policy of denazification is unduly penalising the German people and is increasing the burden on doctors, hospitals and public health officers.' Stayer and his staff insisted that the dateline of 1 May 1937 was 'arbitrary', and 'many who joined the Party before that date had been ignorant or idealistic while many who joined after 1937 were opportunists ... [N]either the date-line, 1 May 1937, nor membership in NSDAP or one of its affiliate organizations are of themselves reliable indications of a man's belief or share in Nazism. This Branch suggests, therefore, that the date-line of 1 May 1937 be abolished and that each case be judged on its own merits, unfettered by this false criterion. ${ }^{, 66}$

The British and Americans had developed their denazification programmes together, and in general developments were similar. But it took significantly longer for American medical officers' urgency argument to have an effect; the British willingness to relax denazification began rather sooner. When in November 1945 the British War Office collected information on the staffing situation in the public health operations in the western occupation zones, British health officers already reported that a decision had been made to 're-employ ... nonactive members of the NSDAP'. In the same survey, the American Health Branch, by contrast, were unsatisfied with the lack of expediency in their 
own zone, especially with regard to denazification. While the British reported that the number of German medical personnel in their zone was slowly becoming 'adequate', both for present and for potential epidemic conditions, the Americans stated that their available German personnel was not adequate for either. ${ }^{67}$

Things did begin to change. A draft of a new policy directive from August 1945 suggested that the 'practical needs' of the occupation officers in charge of industrial issues and reparations ought to be acknowledged. 'Situations have arisen', it stated, 'in which it becomes desirable to make use of the technical skills and experience of certain German specialists, found to be in arrest categories, in the re-establishment of permitted German industrial undertakings when their skills are essential to the operation of such industries and where acceptable personnel with the necessary qualifications are unprocurable.' The relevant division head should be allowed to make a case for using these people to the Public Safety Division, including the 'duties to be performed and qualifications of the individual which appear to make him indispensable', and no such persons were to be used 'except in cases of absolute need', and only temporarily. ${ }^{68}$ Although still relatively strict, such formulations began to allow for the possibility of circumventing restrictions if the circumstances dictated it, and thereby opened the door to more substantial reinterpretations. Health officers used precisely this language to argue that the retention or re-employment of German doctors in dismissal or arrest categories was 'absolutely necessary', and that their qualifications did indeed make them 'indispensable'.

In the British zone, doctors dismissed from public employment (such as those working at hospitals or as medical officers) were allowed to practise privately, since their medical licences remained untouched by the denazification procedures. By contrast, in the American zone there was significant opposition to allowing them to continue to work. In July 1945, one health officer argued that doctors to be dismissed ought to lose their licences completely. It was known, he noted, 'that Doctors, Dentists, Nurses and etc. who previously occupied positions of importance in the Nazi Party and affiliated organisations, when dismissed from their positions, acquired private practices'. Since 'their public contact can be considered as vitally significant', he argued, '[r]emoving this category of personnel from public life without delicensing them is only partly divorcing them from extensive public contact'. He 'recommended that the delicensing of this category of personnel should be included in the decisions where the directives indicate mandatory dismissal. $\underline{\text {, }}$

However, the shortages of qualified personnel, both of medical practitioners and health administrators, prevented the systematic application of such ideas. The zone's authorities gave out temporary licences to maintain a basic network of medical care. ${ }^{70}$ Just as in the British zone, compromises focused on recruitment into unpopular positions in hospitals and administration, where it was difficult not only to find politically acceptable doctors but also to tempt them to take the job. The American health report from July 1946 noted that a major deficiency was the lack of sufficient numbers of qualified health officials, and said that this could, at least in part, be explained by their 'inadequate salaries'. ${ }^{71}$ Others also maintained that in these conditions, jobs in the health administration had to be made more attractive to private practitioners. In Bavaria, the German head of the Bavarian Health Department apparently received a monthly salary of 'some 800 ' Reichsmark, while 'an average successful private practitioner' earned 'in the average some 1,000 RM. This situation is general throughout all public health administrative positions and to a great extent tends to keep any qualified individuals from offering themselves for public office. 72

That recruitment compromises and increased salaries were considered necessary in Bavaria is all the more remarkable because in the whole country, it had the greatest quantity of doctors and the highest ratio of doctors per head of population. During the war, many doctors from across Germany had settled in the comparatively unspoilt Bavarian towns and villages. The resulting surplus was increased further when, in the wake of the Red Army's advance into Germany, many doctors fled to Bavaria from what was soon to become the Soviet-occupied zone. The severe shortages there were matched by Bavarian surpluses. 'At present there are far more doctors in Bavaria than there are available practices,' one American official noted in May 1946, 'Therefore, on the expiration of temporary settlement licenses granted during the war, the Ärztekammer is refusing permanent settlement licenses to refugee doctors in this area. These people are thus forced to return to their home provinces. ${ }^{73}$ However, the high density of private practitioners was not matched by an adequate supply of medical officers working for the health service, and American and German authorities thus argued that a relaxation of denazification was necessary.

The archives document the kind of procedure that was widely practised. Requests were put to the zone's authorities for the retention or re-employment of individuals in the dismissal or arrest categories, occasionally by American medical officers, but usually by German officials or authorities (whether health offices, hospitals, medical faculties, or clinics). These requests were generally granted 'if no military objection exists', and usually none did. ${ }^{74}$ Although American officials sometimes grumbled about the 'administrative burden' of these demands (requests had to travel up 
the military chain of command, and decisions back down again), they generally seemed to 'appreciate the desire to bring back friends [of] accepted established administrations', and did their best to facilitate this process. ${ }^{75}$ The requests were often justified by claims that although the individuals found themselves in a suspect category, they had never been interested in Nazi propaganda or any political causes. The American authorities soon developed and internalized German arguments on why any denazification of the medical profession was unwarranted. As one German doctors' organization put it, 'the German physicians showed an unpolitical attitude indeed, even during the years of the Nazi government - apart from a few exceptions. These few exceptions proved their political interest by entering the NS-party already before it had come to power and being really active in the party or in its organisations. The physicians at large desist from those elements and leave them alone. ${ }^{76}$

These claims of medics' aloofness from politics often confirmed American health officials' own instincts. They regularly supported demands for the appointment of apparently suspect individuals with recommendations from former research colleagues in the United States or Britain. In September 1945 Health Branch officers were delighted when a Dr O'Brien from the Rockefeller Foundation contacted the military government in response to a request for information on a number of German doctors and medical researchers, all of whom he recommended warmly. Among them were the 'outstanding' neurologist Georg Schaltenbrand; the surgeon Wilhelm Tönnis, who had given 'friendly help' to Allied prisoners; and the biochemist Professor Lenhardtz - a 'non-party man', who had maintained, O'Brien wrote, 'a pretty strict scientific attitude about his work'. In all three cases contact had broken down during the war, and in reality O'Brien knew little about their activities during the Nazi regime, but all three had been Rockefeller fellows in the past and were therefore presumed to be suitable for reappointment. ${ }^{77}$

In the absence of reliable testimonials and productive ideas on which Germans were suitable for employment (rather than those who were not), health officers welcomed such recommendations, even if this contradicted the judgement of the denazification branches of military government. Schaltenbrand's past was at best murky, despite his own protestations to the contrary: Paul Weindling has documented some of his medical experiments without consent on mentally disabled persons during the war, which on several occasions had killed his test subjects. ${ }^{78}$ But his medical colleagues in Britain and American rallied to his support. When the British scientist E. B. Strauss toured universities in the French and American occupation zones in the summer of 1946, he said there could be 'no possible doubt' that Schaltenbrand 'was a consistent anti-Nazi' - even if it was unfortunately true that, 'in order to be permitted to continue with his ... work', Schaltenbrand had in 1943 'allowed his name to appear on a list of local party-members'. 'The consequences of this have been tragic', Strauss argued: not only was Schaltenbrand's house requisitioned, leaving him, his wife, and four children homeless, but he was also sacked from his post at the University Hospital in Würzburg. ${ }^{79}$ But while British and American scientists argued for his innocence, those in the denazification branches were unconvinced. When the Allied Field Information Agency (FIAT) commissioned him to write a survey of the state of neurology in Germany, he was removed from his hospital post. ${ }^{80}$ The lack of a consensus between different parts of the occupation machinery could hardly have been more striking.

The files contain many other cases of tarnished reputations and Allied attempts to save them, such as that of Professor Carl von Hindelang, who, as a 'son of a well-known Nazi activist' and with 'a history of considerable Nazi activity with decorations', found himself in the 'non-employment mandatory' category. The bishop of Chichester wrote a recommendation, explaining that although Hindelang had 'put his trust in Hitler', in fact 'Germany was to him much greater than Hitler'. He had been uncomfortable with some Nazi policies, 'particularly with regard to the Jews'. Hindelang had already 'repented of his Nazism before the war, and at real cost to himself'. In addition, the bishop went on, Hindelang was 'a brilliant doctor, and it would be a real tragedy if he were permanently prevented from exercising his remarkable gift'. Other references followed. 'A well-known American Dr' wrote that 'the world' would be 'losing a great deal if [Hindelang] is not permitted to continue.' A British solicitor and former patient of Hindelang's thought that the German physician had discovered a substitute for insulin, and insisted that it would be a 'tragedy' if he was not allowed to 'use his skill as a specialist' and save lives when 'the need is so great'. The Public Health Branch wanted to reconsider Hindelang's case, swayed by 'Prof. Carl's apparent high professional standing'. But the case had already been handed over to a German tribunal, and there was little they could do. ${ }^{81}$

Another revealing case concerned Professor Max Hochrein, on whose behalf Paul Dudley White, a well-known and well-respected physician at Massachusetts General Hospital who later became Eisenhower's cardiologist, wrote to the American authorities in Germany. Hochrein had been a long-standing member of the NSDAP, and, following a period of internment, was still out of work in spring 1946. White explained that Hochrein had been 'an acquaintance of mine extending over a good many years', and he thought that, 'despite his Nazi party membership, he should be allowed to 
do medical work in Germany for the good of his people. He is an able man and doubtless can help to improve the standards of medical care and even of clinical investigation in his own field. ${ }^{82}$ The Health Branch took this recommendation very seriously. 'Because of your letter', they replied, 'this office has taken more than ordinary interest in Professor Hochrein and will try to give him assistance in locating in some city where he could return to his specialty. The possibility of getting Professor Hochrein located with one of the Medical Faculties in the U.S. Zone is being given consideration. Undoubtedly his present situation is most unsatisfactory to him and it is unfortunate that his training and ability are not being utilised fully. ${ }^{83}$ Although they failed to find him a job, it was not for lack of trying. But by then many of the direct responsibilities of selecting and employing Germans had already been handed over to the German authorities, who were not nearly as keen on Hochrein ${ }^{84}$ or perhaps resented being told what to do by the occupiers. American health officials shared White's disappointment, they wrote later, and his interest was 'deeply appreciated', but 'under a policy of delegating full responsibility to the Germans for the management of their own internal affairs as rapidly as possible, Military Government refrains from directing the placement of individuals, .85

The cases of Hindelang and Hochrein show that 'indirect control' was a real feature of health work in the American zone. This is explored further below. But for denazification priorities, these examples illustrate the power of references and testimonials from the scientific establishment abroad. They point to the existence of a set of scientific and medical connections between German doctors and medical colleagues abroad, who protected and aided them in their post-war careers, especially in the absence of other criteria. It was, after all, American policy 'to encourage the reestablishment of relations between members of the German medical profession and associations of medical men elsewhere in the world, 86

Practical compromises were made later in the American zone than in the British, but the kinds of arguments used by health officials were similar and eventually had similar results. In addition, these compromises often found fertile soil because American officials were much more explicit than their British counterparts about having to bring 'American concepts and traditions' to the defeated, and teaching democracy. ${ }^{87}$ As Lucius Clay put it, the 'Development of Democratic Attitudes and Methods' had to be one of the main features of the American occupation; and so some morally compromising policies could be tolerated and justified if they helped German democracy. ${ }^{88}$

In autumn 1945, as non-fraternization regulations were lifted, and Americans were officially allowed to talk to and interact with German civilians, Eisenhower reminded the US forces that the real work had only just begun: 'the shooting war' had been won, but 'the war for men's minds' was still going on. American soldiers had to be 'democracy's best ambassadors'. ${ }^{89}$ Once occupation staff's wives and children joined them in Germany, they, too, were drafted into the democratization mission. Although they invariably lived in requisitioned houses or apartments, they were to introduce a humane element into the occupation and teach values such as compassion and benevolence. As representatives of a society 'that enjoyed prosperity and democracy without persecuting or exploiting other peoples', they were an example of democratic family and home life. ${ }^{90}$ Democratization rhetoric was present even in arguments about German appointments. In September 1945, military government departments were encouraged to use Germans as technical advisers and consultants, especially if they had 'known liberal views'. ${ }^{91}$ They were to be taught 'that in a democracy all employees of government, whether provisional, advisory, or permanent employees, are in very real sense the literal servants of the people'. ${ }^{92}$ The conviction that Germans should and could learn about democratic methods and processes led to the belief that military government ought not to intervene in their work, and made real 'indirect control' by American authorities more straightforward than in the British zone.

\section{Confrontations}

Conflicts were an unavoidable feature of the occupation, and took place over a range of predictable issues. At the outset, émigrés and antifascist activists resented the Allies' proclamations of collective guilt and the fact that they were not consulted on what the new Germany should look like. During the occupation, complaints came from all corners of the zone about officers' 'dictatorial ambitions' and attempts to 'run their places like little kingdoms', which had the effect of 'atomising Germany even beyond the four-zone split'. ${ }^{93}$ Other grievances concerned the shortages in food and other supplies, together with luxurious American lifestyles, pompousness, bureaucratic officiousness, or lack of interest in German suffering.

Many of these German complaints found American advocates, who used the American press to vent their views. An essay entitled 'Malice in Blunderland' described at length the contradictions and ineptitudes of American policy in 
Germany, where brutish American officials lived off the land, implemented obstructive, short-sighted, and punitive programmes for personal gain, and failed to understand what was at stake. The author, Joan Crane, was married to an OMGUS economic adviser in Berlin. 'The military here,' Crane wrote, 'with their rigid caste system and their punitive attitudes, are not the best group to demonstrate democracy to a foreign nation. Brigadier generals, like the Cabots and the Lowells, ${ }^{94}$ have an inclination to mingle with themselves, colonels and majors with colonels and majors. Neither is a West Point training especially conducive to the development of imagination in the field of human relations.' Nor were they any better at picking suitable civilian advisers: 'Advising OMGUS you will find scarcely an economist or sociologist of distinction in his own field. Top policy-making and advisory jobs have gone to unknown professors from second-rate colleges, minor business men and salesmen suddenly turned "economic experts", and obscure lawyers - docile men for the most part, content to follow rather than to guide the military.' Visiting American industrialists were only interested in making a quick buck. Quoting a report submitted to the US Senate in December 1946, a shocking 25 per cent of the US forces in Germany had scored 'feeble-minded or only slightly above' in IQ tests, she maintained, and only 2 per cent 'showed enough intelligence to do satisfactory college work'; 10 per cent were 'not even high grade morons'; And such 'ignorant, sub-standard troops' were 'costing the American people $\$ 11,200$ per man to support for each year that they remain in Germany'. ${ }^{95}$ The Saturday Evening Post refused to print the article, its foreign editor explained to the military government, 'on the grounds that it was overall too one-sided' 96 — but other critical stories did make it to press. ${ }^{97}$

Even though the denazification criteria had relaxed by December 1945, dissent on the policy continued. By mid-1946 concerns began to be voiced about the lack of any real cleansing in the health service. Dr Gerlach, a German medical officer, complained to the American authorities about the 'repeated cases where physicians, having belonged to the former national socialist party, or having had connections thereto, have been appointed [as] Hospital Directors, by a local office, in spite of there having been available equally well, or better qualified absolutely unincriminated candidates'. He demanded that 'politically unincriminated physicians — if equally qualified — should be granted preference over incriminated ones'. Neglecting to do so would mean that 'almost all' former hospital directors would simply be able to walk back into their old jobs. ${ }^{98}$

Faced with such criticisms, American officers, although often sympathetic, usually felt compelled to defend 'pragmatism'. As Leon Standifer put it later, 'Our image was, and still is, pragmatism'; and 'pragmatism means getting the job done even though that may require the sacrifice of ethics, honor, and integrity'. Such pragmatism was required particularly in handing civil control over to any Germans who were able to do the job, regardless of their political history. ${ }^{99}$ Philip Beckjord, chief of the Public Health Branch, replied to Dr Gerlach that 'the Minister of Liberation might well require the Ärztekammer to draw up lists of doctors who are both professional[ly] suitable, and the least politically incriminated, for certain public positions, i.e. hospital service chiefs'.

This phrase on 'the least' politically incriminated shows how far things had come. Beckjord admitted he was 'very uneasy' over the extent of denazification in the medical professions. As far as he was aware, he wrote, 'no former Nazi who was supposed to have stopped practicing on August 1, either privately or in hospital, has done so. There are hundreds of such cases.' OMGUS had issued an order to rescind all temporary medical licences from 1 August 1946. But by this deadline, Beckjord observed, 'blanket extensions' were granted and 'the status quo [was] allowed to drift on in a welter of administrative confusion and conflicting interpretations'. The fact was that military government had 'issued an order which the Germans could not, or did not, carry out because of the feared effect on the public health', which had to take priority, even if American prestige suffered as a result. Ultimately, he argued, temporary licences should be extended until each case could be assessed properly. He did not believe the occupiers 'could really force the licencees to stop practicing. If we did, the public reaction would be terrific - about 406 of the profession would be affected; 250 doctors in Stuttgart alone. ${ }^{, 100}$ This reference to a public reaction against any more substantial denazification shows that concerns went far beyond the simple epidemic fears.

The American military governor's monthly report for October 1945 noted that the Germans had become 'somewhat bolder in their criticisms of Military Government policies'; apart from attacks on non-fraternization, 'the chief German reaction continued to be centered on the subject of denazification'. There was still a portion of the population, 'largely concentrated in the more extreme Left parties, which feels that denazification is not thorough enough and that mere removal from office does not constitute sufficient punishment', but most Germans thought the opposite: 
what they feel is the unjust inflexibility of the American denazification policy. These people are for the most part favorable to punishing 'real' Nazis but they dislike the fixing of an arbitrary date (1937) for judging the guilt of party membership. They claim that many of those who joined the party in the early days later repented of their move, whereas those who joined after 1937 were in many cases among the most ardent Nazis. They feel, further, that the punishment of dismissal is too indiscriminate as it places the heaviest burden on the lower middle class. They also repeat the familiar argument that extensive dismissals interfere with efficiency. ${ }^{101}$

The denazification report for the same month observed considerable public disquiet and sympathy for 'discharged Nazi small-fry', demonstrated by 'increasing numbers of petitions written [on] behalf of these ousted officials. Many are written by clergymen, others by respectable merchants and businessmen.' In some places, church groups had been 'especially active in an effort to reinstate teachers, on the grounds that many teachers joined the Nazi Party to prevent true Nazis from being hired as teachers'. ${ }^{102}$ Denazification strained relations between occupiers and occupied throughout the early years of the occupation, and subsequent U-turns created further enemies. As William Griffith (the denazification adviser to the Office of Military Government for Bavaria), wrote in 1950, denazification policy had been a 'fiasco' and a 'failure'. Although '[m]ost United States denazification personnel were technically competent, hard-working and sincere', he regretted that 'their crusade for "real" denazification rested upon a faulty analysis of Germany and of Nazism, and — most important — of United States policy development. Although they, more than the rest of Military Government, glimpsed the problem of the overthrow of authoritarianism (militarists, industrialists and bureaucrats) behind that of the overthrow of Nazism, they dissipated their efforts on the small fry, and never grasped the exigencies of time and numbers. By the time they accepted the prevailing German standpoint that only Nazis should be attacked, it was too late even for that. ${ }^{103}$

Apart from the more zealous American attempts to denazify the medical profession, the clashes and tensions between occupiers and occupied on health questions generally mirrored those in the other zones. Germans particularly resented that the priority of American public health work concerned the protection of American and Allied troops, with German health and welfare much lower on the list. As late as November 1946 German health departments were reminded that their primary task was to control infectious diseases and 'to eliminate public health hazards which may threaten the safety of the occupational forces or which may interfere with Military administration of Germany, or which may create a hazard for other countries of Europe or the world' - and they continued to object to such a prioritization of Allied health concerns over German problems. ${ }^{104}$ German health officers particularly resented that American health authorities, just like the British, French, and Soviet, took the rising rates of venereal diseases much more seriously than diseases which did not affect their troops, such as tuberculosis. 105

However, relations between Germans and Americans were less complicated than those with the other occupiers, primarily for two related reasons: the Americans were more popular in general, and they had considerably more resources at their disposal. There was less overt hostility towards American soldiers, and public opinion surveys demonstrated that both the behaviour and the popularity of the American troops steadily improved as the occupation progressed. Only a minority of those polled felt that the Americans enriched themselves or had wasted or destroyed German property, and only a small proportion reported having 'unpleasant experiences with Americans'. ${ }^{106}$ A poll in early 1946 showed that the majority of inhabitants in the American zone were optimistic that reconstruction would be accomplished with some degree of speed, energy, and fairness. ${ }^{107}$ A survey in spring and summer 1947 revealed that the majority of Germans in the zone thought that the United States would wield the most influence in world affairs, and it would be directed towards peace. Of the four Allies, the United States was most trusted to treat Germany fairly, and an overwhelming majority thought they were better off than those in the other three zones, and would have chosen the United States as an occupying power. 108 These sentiments made the tasks of the occupiers much more straightforward and conflict-free.

Berliners in the western sectors were most likely to take a pro-American position, even before the blockade of 19489. Health officers were no exception. Those in the western city districts eagerly awaited the arrival of the Americans in the summer of 1945, complaining about the months of sole Soviet rule. At a Berlin Magistrat health office meeting in July 1945, shortly after the American, British, and French had taken over their districts, Dr Emanuel and Dr Redeker assured the assembly that things were going to get better now that the US occupation troops had arrived. The 'Americans want to help', they insisted, and it was 'even likely that they will send us some medicaments as soon as they can'. ${ }^{109}$ After July 1945, when the Berlin-wide health officials had regular contact with all four authorities, the Americans continued to be the most popular. At a Magistrat meeting in August 1945, Colonel Scheffers from the American Health Branch was given a warm welcome. He and his colleagues were there to help, Scheffers said, and he 
was convinced it was possible to work in friendly cooperation with the Germans. Only 'the necessity for agreement with all Allied powers makes our work much more difficult', he told them. Whether he was referring to problems with French or Soviet obstruction (or both) is unclear, but it was a sentiment which the German health officers sympathized with. ${ }^{110}$ When Russian officers appeared at these meetings, by contrast, it was mainly to complain that disease rates were still too high and that not enough had been done to carry out Soviet instructions, which did not endear them to the Germans. 111

American resources made a huge difference. The arguments about malnutrition and tuberculosis that erupted in the British zone never did so to the same extent in the American zone. The United States was the richest of the occupation powers, and the Ally least affected by the war - and contributed, and was seen to contribute, generous quantities of material supplies, food, and aid. From their arrival, Germans were struck by American affluence and generosity. As Heide Fehrenbach notes, 'The stereotype of the gum-chewing, chocolate-bar dispensing GI originated both in the actual social practices of U.S. occupation troops and in German perception of these behaviors as somehow uniquely American.' It served to differentiate them from the British and particularly the Soviets and French. ${ }^{112}$ Germans in all zones were convinced, correctly, that food rations were largest and more regularly delivered in full, in the American zone. $^{113}$

That is not to say that there were no serious shortages and supply problems. But American occupation officials argued - much more explicitly and forcefully than their British counterparts - with those at home unhappy about the occupation costs, that the democratization agenda could only succeed if Germans lived reasonably comfortably. Economic and political freedom was essential: material aid could help to convince Germans both about the reality of American support and the potency of American democracy. ${ }^{114}$ Lucius Clay repeatedly pointed out that 'democratic processes' could only succeed 'in an atmosphere of political and economic stability', ${ }^{115}$ and that the shortages of food and essential items such as fuel 'were not conducive to the creation of interest in the ways of democracy'. ${ }^{116}$ At least in part this argument helped to convince sceptical politicians in Washington to agree to substantial increases in imports for German consumption. ${ }^{117}$ While similar arguments also took place within the other Allied governments, the United States was least constrained by economic crises and supply problems at home and thus most able to respond generously.

As a result, supply problems were simply not as acute as in the other three zones. The costly new drug penicillin was made available for the treatment of venereal diseases earlier and in greater quantities than in the rest of Germany: the American Health Branch requested the War Department to provide penicillin for the treatment of gonorrhoea among the Germans as early as September $1945 .{ }^{118}$ Some German health officers were disappointed that penicillin was not then provided for other diseases, but it did immediately make the treatment of venereal diseases much more popular. Health officers noted that the numbers of registered cases 'increased markedly with announcements that penicillin was available for treatment of infected civilians' ${ }^{119}$ By December 1945, penicillin treatment for gonorrhoea was widely instituted, and the numbers of Germans treated continued to rise. ${ }^{120}$ In January 1946 the German authorities were authorized to supervise most penicillin treatments themselves, and by spring 1946 large quantities of the drug had been made available. ${ }^{121}$ By September 1947 supplies had increased to a monthly allocation of 21 billion units of penicillin for the zone: only 2 billion were needed for gonorrhoea, 12 billion units were used to treat syphilis, and 7 billion units were available for the treatment of non-venereal diseases. ${ }^{122}$ At the same time, the Soviet zone suffered from severe shortages of penicillin, and even in the British and French zones it was not available in such plentiful capacities.

Debates between American and German doctors were also less severe because of the greater, and earlier, American willingness to put responsibilities into German hands. This tendency towards 'indirect control' was facilitated by two separate features of American policy. First, the urgent priority to release military forces for duties in the Pacific, and, after that, to discharge them to cut occupation costs, required that the American zone should be administered with as few American personnel as possible. For this reason alone German authorities thus had to be reinstated quickly, used consistently, and trusted to work effectively. Second, the desire to create a federal democratic system meant that the German population needed to be taught democratic methods. They could not easily learn without practical experience in administrative and governmental affairs, even if only initially at the local levels. Once they had mastered local practice they could acquire regional and national powers. To this end, the reconstructed German administrations were decentralized on the federal model at the level of the Land (or, as the Americans called it, the state). 
In practice, these three issues - demobilization pressures, the democratization agenda, and the federal model —were closely intertwined. In September 1945, Lucius Clay wrote to John McCloy (assistant under-secretary of War, Clay's successor as American military governor, and a future Allied high commissioner in Germany) that the Germans had to be encouraged to take on administrative responsibilities. Local governments should be restored as soon as possible so that Germans could take on 'definite authority to handle local problems without supervision from above'. Local elections had to be held at the first opportunity, since they were 'one of the most important [components] in reestablishing democratic attitudes and methods'. These elections, Clay argued, would 'give the Germans an opportunity to learn democratic procedures on the lower levels before undertaking elections for larger units. At the same time, the election of such local officials will tend to relieve Military Government of many duties at that level. ${ }^{123}$ A few weeks later Clay spelled out even more clearly how these issues overlapped: 'If the Germans are to learn democratic methods,' he wrote to McCloy,

I think the best way is to start them off quickly at the lower levels. Besides, this will help us reduce substantially the personnel required for Military Government. With so many officers returning to the United States during the coming months, we will certainly not be able to staff a large number of the local detachments with qualified men even by a vigorous recruiting program. Yet, we can hardly withdraw the local detachments until the officials appointed by us have been replaced by others selected by the Germans. When this has been done, I think we can effectively supervise their activities from the next higher level. ${ }^{124}$

As a result, as early as September 1945 the Americans created federal administrations for each Land with full legislative and executive powers, and from the start the German heads of these authorities, the minister-presidents, had more authority and independence than their counterparts in the other zones. ${ }^{125}$

The weight of administrative and governmental work was given to German staff some time before this was done in the British zone-including in the realm of public health. As the zone's health report for January 1946 noted, 106 American medical officers in military government detachments had been redeployed, and by 1 June 1946 there would be no more than 33 officers, with only 17 officers anticipated to remain by the end of June. The disbanded officials had been replaced by German civilians, 'as the latter resumed satisfactory direction of public health'. ${ }^{126}$ Other reports listed the various responsibilities that had already been, or were soon going to be, handed over to the German health authorities. ${ }^{127}$ By January 1946, significant changes had already taken place: German public health authorities resumed more or less complete responsibility at the local level, German-run nutrition teams were about to replace the American teams in operation, ${ }^{128}$ and American personnel were being withdrawn below the level of the Land. ${ }^{129}$

Some conflicts persisted nonetheless. How far Germans could be trusted to carry out their newly regained responsibilities continued to be a matter of debate and disagreement, particularly after the British and American zones were merged into the economically unified Bizone in January 1947 (followed in April 1949 by addition of the French zone, just weeks before it became the Federal Republic of Germany). Some British occupation officers were dismayed about the Americans' heavy reliance on German authorities, before, they argued, any real reforms or changes in character or outlook had been achieved. As one British report observed, 'Americans are convinced of the superiority of their handling of German administrative problems and of their general approach to the Germans, individually. Far more confidence is shown in the Germans, more authority delegated to them and greater social intercourse permitted.' It was not unusual for US authorities to organize a Bierabend (an evening of communal beer-drinking) after their meetings, 'where German men and women and American men and women mixed freely'. The report went on that the Americans found it 'difficult to understand why we [the British] do not always adopt similar practices'. Particularly 'in the administrative and economic field' the Americans failed to 'appreciate that the uncertainty of the political state of the Ruhr and the heavy industrialization of our Zone presents us with a different set of problems'. ${ }^{130}$

British medical and nutritional officers worried that their American colleagues were being duped, and cautioned them against an over-reliance on German data. At a joint British-American Public Health Conference in Berlin in September 1947-just when the debates about nutrition and tuberculosis were about to escalate in the British zoneBrigadier W. Strelley Martin (from the British Control Commission's Public Health Office, and British representative on the Combined Nutrition Committee), warned his American colleagues 'against false German propaganda on health and nutrition matters'. He proposed that the Information Control Division should take over 'control of such matters' (i.e. the collection and analysis of medical and nutritional data), rather than leave it to Germans. 131 
Although there were fewer direct confrontations between American and German health officials about malnutrition and nutritional research, they did, just like in the British zone, fundamentally disagree about the significance of tuberculosis. ${ }^{132}$ Following the publication of the British report on tuberculosis, the American authorities ordered an investigation of conditions in their own zone. ${ }^{133}$ The commission was headed by an eminent US tuberculosis specialist, Esmond R. Long, and came to similar conclusions. ${ }^{134}$ While the German public health authorities had claimed a sharp increase of tuberculosis, this was not evident to the American specialists. The German authorities argued that although tuberculosis death rates had not actually increased yet, there was a lag between the rise in cases and the rise in deaths, and that an increase in the mortality rate was imminent. However, the American commission thought that the German 'data on incidence and prevalence are to be little trusted and that death rates are, under present conditions, the only reliable index of the trend of tuberculosis today'. Like their British colleagues, although not in as biting terms, they pointed out that 'the reliability of German postwar morbidity statistics' was called into question by the 'availability of ration supplements to tuberculosis cases ... In view of the acute food shortage, it is only natural that these supplements should prove an incentive to the reporting of cases that would otherwise not be reported. 135

These kinds of findings sat uneasily with the American agenda of democratization and self-sufficient German health authorities. But the American rejection of these particular German claims was not, however, accompanied by a more general rejection of German legitimacy and ability to take control over public health functions, and during and after this episode Americans continued to hand over responsibilities to the German health authorities.

This insistence on handing administrative and basic governmental powers to German appointees and offices became even clearer after the reformulation of American occupation policy during 1947. Shortly after the re-elected President Truman's appointment of George Marshall as Secretary of State in January 1947, the basic occupation directive, JCS 1067, was replaced with a new document, JCS 1779. Unlike its predecessor, the new programme stated that a stable and prosperous Europe depended on substantial economic contributions from a stable and prosperous Germany; that the European economy would not recover without a strong German industrial base. ${ }^{136}$ Lucius Clay officially received the directive from Washington in July 1947, and a press release explained that the new policy's aim was to provide 'measures which will bring about the establishment of stable political and economic conditions in Germany and which will enable Germany to make a maximum contribution to European recovery'. ${ }^{137}$ The economic agenda was accompanied by political instructions to the zone's authorities, and the new occupation directive urged Clay to take an active part in shaping the minds of the people in western Germany.

Where the first directives had made it clear that Germans were to be treated as an occupied population in a defeated (rather than a liberated) country, the new directive emphasized the importance of welcoming Germany as a new ally, and building a bulwark against the Communist East. In quadripartite meetings the United States continued to demand a German economic union, a central production and foreign trade programme, and a central administration for overseeing reconstruction work in all four zones: but in practice the American approach had changed radically. Marshall's announcement of the European Recovery Programme in June 1947 confirmed Washington's intention to rearm Germany and prevent it from falling under Soviet rule. Marshall Plan aid would jump-start the economies of western Germany and the other European allies and remove the material basis of discontent, but also restore confidence in free market democracy and provide a strong alternative to communism. By 1950, the economic rehabilitation of West Germany as a keystone of Western European recovery was entrenched in American foreign policy and had already shown substantial successes. And few American politicians or occupation officials would have denied then that US aid - initially in the form of emergency GARIOA (Government and Relief in Occupied Areas) funds of around 1.9 billion dollars, followed by around 780 million dollars in reconstruction grants from the Economic Cooperation Administration by $1950^{138}$ — was central to the process.

In 1950, Robert Engler, who had returned from service in Germany in late 1945, presented a rather pessimistic view of the American occupation. Americans had made many mistakes along the way, he declared: 'Not deeply interested in European politics or ideology, the American often assumed that non-Nazis were always anti-Nazis, and anticommunists were always democrats. Like many of his civilian friends, he equated capitalism with democracy, and was perturbed by those who substituted socialism. He was sure that the way Americans did things was best, and was eager for people to adopt baseball, Coca Cola and democratic elections. But he was suspicious of parties and politicians.' Americans had not appreciated the 'discrepancies between ideals and realities of the American way', Engler complained, and had failed, ultimately, 'to recognize the occupation as an imperative part of their new world obligations'. It was 'too early to predict the outcome', he concluded, since 'the discouraging patterns of so much of 
present-day Germany suggests how difficult an objective we have set for ourselves and how much of the job still lies ahead'. 139

But the absence of some of the conflicts that plagued the British zone was, in part, the result of different American priorities, which became more pronounced as the occupation went on. The focus on 'democratization' and the desire to build self-sufficient local and regional administrations on the federal model came from a combination of practical and ideological calculations, and, along with generous resources, helped to override some of those contradictions inherent in the occupation set-up. Where British staffs were paralysed by the apparent impossibility of remoulding totalitarian minds while keeping essential jobs staffed — of instituting 'indirect control', without fully trusting Germans to do the right job - the Americans believed in the transforming attractions of the 'American way of life'. No doubt a naïve belief in the power of baseball and Coca Cola helped a great deal. Most important of all, however, was the very different economic context of American policy, which was able to answer German concerns about starvation and malnutrition, rising tuberculosis rates, and a host of other public health problems with food, with drugs, and with substantial material aid. ${ }^{140}$

\section{Footnotes}

1 BAK, Z45F, 3/169-2/159, 'Minutes of the Meeting convened by Chief, Public Health Branch, G-5 Division, SHAEF, for discussion of military government public health plans and operations', 15-16 Jan. 1945.

2 Richard R. Taylor (ed.), Preventive Medicine in World War II, viii. Civil Affairs/Military Government Public Health Activities (Washington, 1976).

3 JCS 1067, 'Directive of the United States Joint Chiefs of Staff to the Commander-in-Chief of the United States Forces of Occupation regarding the military government of Germany', Apr. 1945, repr. in Beate Ruhm von Oppen (ed.), Documents on Germany under the Occupation, 1945-1954 (London, 1955).

4 BAK, Z45F, 3/153-3/15, 'Chart indicating functional relationships between Ministries, Control Commissions/Councils and Staff Agencies', USGCC (Mil Gov Div B, Displaced Persons Section) to Director (Division B), 5 Nov. 1944. This chart listed the Ministry of the Interior, Dept IV and the Reich Public Health Office as the German health bodies that future health officials of the occupation authorities would have to liaise with and supervise.

5 Eisenhower Proclamation No. 1, Amtsblatt der Militärregierung Deutschlands, Amerikanisches Kontrollgebiet, quoted in Christoph Weisz (ed.), OMGUS-Handbuch: Die amerikanische Militärregierung in Deutschland 1945-1949 (Munich, 1994), 9.

6 Dwight D. Eisenhower, Crusade in Europe (London, 1948), 471, 473.

7 e.g. A. Königseder in Wolfgang Benz (ed.), Deutschland unter alliierter Besatzung, 1945-1949/1955: Ein Handbuch (Berlin, 1999), $114-15$.

8 Quoted in Paul Weindling, Nazi Medicine and the Nuremberg Trials: From Medical War Crimes to Informed Consent (Houndmills, 2004), 39. Many thanks to Paul Weindling for information about Rosen's role in compiling this pamphlet.

9 William E. Griffith, 'Denazification in the United States Zone of Germany', Annals of the American Academy of Political and Social Science, 267 (Jan. 1950), 68-76, at 68.

10 Griffith, 'Denazification', 68.

11 e.g. Klaus Mann, The Turning Point: The Autobiography of Klaus Mann (1942; London, 1987). For other examples see Marita Krauss, Heimkehr in ein fremdes Land: Geschichte der Remigration nach 1945 (Munich, 2001).

12 Theodor W. Adorno et al., The Authoritarian Personality (1950; New York, 1982), p. viii.

13 TNA, FD 1/6046, 'Report of a Conference on Germany after the War', [undated].

14 Gorer's first OWI study was published as Japanese Character Structure and Propaganda (New York, 1942), 'Themes in Japanese Culture', Transactions of the New York Academy of Sciences, ser. 2, 5 (1943), 106-24, and 'The Special Case of Japan', Public Opinion Quarterly, 7/4 (Winter 1943), 267-82. See also Geoffrey Gorer, Burmese Personality (New York, 1943). After GPRB was closed, Gorer returned to the US and worked on US-based research projects such as Studies in Soviet Culture, coordinated by the American Museum of National History. Weston La Barre, 'Columbia University Research in Contemporary Culture', Scientific Monthly, 67/3 (Sept. 1948), 239. See also Geoffrey Gorer, ‘The British Zone of Germany', Fortnightly (Dec. 1946), 281-7. 
15 Lucius Clay, Decision in Germany (London, 1950), 281-2.

16 Carl J. Friedrich, 'Military Government and Dictatorship', Annals of the American Academy of Political and Social Science, 267 (Jan. 1950), 1-710.1177/000271625026700102 [CrossRef], at 4.

17 JCS 1067, 'Directive', Apr. 1945.

18 Popular histories of the last war months and the Allied armies' first contact with the Germans include Max Hastings, Armageddon: The Battle for Germany, 1944-1945 (London, 2004), and Barry Turner, Countdown to Victory: The Final European Campaigns of WWII (London, 2004). Also see Richard Bessel, Germany 1945: From War to Peace (London, 2009).

19 George Orwell, 'Bavarian Peasants Ignore the War: Germans Know They Are Beaten', Observer, 22 Apr. 1945, repr. in Orwell: The Observer Years (London, 2003), 46.

20 Tom Pocock, The Dawn Came Up Like Thunder (1945; London, 1983), 88. Turner, Countdown to Victory, $341 \mathrm{ff}$. The US Third Army liberated Buchenwald in Apr. 1945; the Seventh Army troops liberated Dachau on 29 Apr. 1945.

21 George S. Patton, War as I Knew It (1948), in Martin Blumenson (ed.), The Patton Papers, ii. 1940-1945 (1974). Also quoted in Leon C. Standifer, Binding Up the Wounds: An American Soldier in Occupied Germany, 1945-1946 (Baton Rouge, La., 1997$), 71$.

22 IWM Sound Archive, Dr William Robertson, 'An American doctor talking on conditions in Germany at the end of the war', Thames TV interview recorded in 1972.

23 Standifer, Binding Up the Wounds, 146-7. Also see Leon C. Standifer, Not in Vain: A Rifleman Remembers World War II (Baton Rouge, La., 1992).

24 Leslie V. Tischauser, The Burden of Ethnicity: The German Question in Chicago, 1914-1941 (New York, 1990) —one of many regional studies of Germans in the USA, points out that German-Americans had not experienced a revival like other ethnic groups in the US 'because the building-blocks of an ethnic consciousness, language and loyalty to the old homeland, were lost between 1914 and $1941^{\prime}, 261$.

25 Kathleen Neils Conzen, 'Germans', in Stephan Thernstrom (ed.), Harvard Encyclopedia of American Ethnic Groups (Cambridge, Mass., 1980), 405-25, at 406. There is a large historiography of German immigrants and their descendants in America, see e.g. Frank Trommler (ed.), Amerika und die Deutschen: Bestandsaufnahme einer 300jährigen Geschichte (Opladen, 1986). LaVern J. Rippley, The German-Americans (Boston, 1976). Albert B. Faust, The German Element in the United States, 2 vols. (1909; New York, 1969).

26 'Eisenhower: a factual sketch', Time, 7 Apr. 1952. An early biography of Eisenhower narrates how Eisenhower's ancestors first arrived in America, see Francis Trevelyan Miller, Eisenhower, Man and Soldier (Philadelphia, 1944); while another discusses the Eisenhower family ancestry at length but focuses almost exclusively on religion, see Kenneth Sydney Davis, Soldier of Democracy: A Biography of Dwight Eisenhower (New York, 1946). Among more recent biographies are Carlo D'Este, Eisenhower: A Soldier's Life (London, 2002); Douglas Kinnard, Eisenhower: Soldier-Statesman of the American Century (Washington DC, 2002); Stephen E. Ambrose, Eisenhower: Soldier and President (1990; new edn. London, 2003).

27 Robert Engler, 'The Individual Soldier and the Occupation', Annals of the American Academy of Political and Social Science, 267 (Jan. 1950), 82.

28 Engler, 'Individual Soldier', 82.

29 BAK, Z45F 44-45/4/6, 'Policy and instructions on relations with the Germans of Allied Armed Forces and Control Commission Staffs in the initial period of control', [21 Dec. 1944] and subsequent documents in this folder. On the fraternization policy and reality, see Maria Höhn, GIs and Fräuleins: The German-American Encounter in 1959s West Germany (Chapel Hill, 2002); Robert Moeller, Protecting Motherhood: Women and Family in the Politics of Postwar Germany (Berkeley, 1993).

30 e.g. BAK, Z45F, 44-45/4/6, Lt. Muelder to Col. Calder, 26 May 1945.

31 BAK, Z45F 44-45/1/6, press conference report, 16 May 1945.

32 BAK, Z45F 44-45/4/6, minute by Parker Buhrman (Political Division) to Colonel Carter and Robert Murphy, 15 June 1945. Parker Wilson Buhrman was US consul general in Munich, 1945-6, following a long career as an American diplomat.

33 BAK, Z45F 44-45/4/6, minutes by Colonel Henry Carter and Robert D. Murphy, 23 June 1945. Compare to Murphy's critical assessment of the non-fraternization rule later on, Murphy, Diplomat Among Warriors (London, 1964).

34 BAK, Z45F 44-45/4/6, minute by Colonel Henry Carter (Acting Chief, Office of the Secretary General) to General Milburn, 23 June 
1945.

35 BAK, Z45F 3/169-2/159, Colonel Scheele (Chief of the SHAEF Preventive Medicine Section) at the public health meeting of 15-16 Jan. 1945, p.16.

36 TNA, FO 1050/10, W. Boucher to PM Balfour, 3 Dec. 1945.

37 TNA, FO 1050/10, Legal Branch (Mil Gov Hannover) to Legal Division (CCG (BE)), Dec. 1945.

38 BAK, Z45F 44-45/4/6, order from Eisenhower to commanding generals, 4 June 1945.

39 BAK, Z45F 44-45/4/6, order from Eisenhower to all members of USFET, 27 Sept. 1945.

40 Annette F. Timm, The Politics of Fertility in Twentieth-Century Berlin (New York, 2010), 189.

41 e.g. TNA, FO 371/51418, Rt. Hon. P. J. Noel-Baker, MP (Minister of State) to Clement Attlee (PM), 13 Dec. 1945. The Red Cross teams nicknamed UNRRA 'You Never Really Relieved Anybody', see Caroline Moorehead, Dunant's Dream: War, Switzerland and the History of the Red Cross (London, 1998), 506. Also see TNA, FO 1050/10, D/Chief (IA\&D Div, Bünde) to Boucher (Director, health branch, Bünde), 6 Nov. 1945.

42 e.g. IWM 12511 02/49/1, Frederick Morgan's diary — written while he was director of operations in Germany for UNRRA (1 Sept. 1945 to 27 Aug. 1946), includes accounts of visits to DP camps and meetings with UNRRA and military personnel. A sanitized account appears in a chapter of his autobiography, Lieutenant-General Sir Frederick Morgan, Peace and War: A Soldier's Life (London, 1961).

43 Standifer, Binding Up the Wounds, 22.

44 TNA, FO 371/46992, Monthly Report of Military Governor, US Zone, No. 3, 20 Oct. 1945, sent to the Foreign Office for information.

45 'Public Health and Medical Affairs: a supplement to the Monthly Report of the Military Governor, U.S. Zone', No. 4, 20 Nov. 1945 , 16 , noted that the minimum ration of 2,300 calories per person per day was provided in DP centres, and Red Cross packages and other non-rationed foods created an additional surplus. See also table ix, 'comparison of adult weight data, 1945, United States Zone', 16.

'Public Health and Medical Affairs', No. 2, 20 Sept. 1945, 1, and table i: Distribution of Military Government Medical Personnel, U.S. Zone of Germany, 1 Sept. 1945, 8.

47 'Public Health and Medical Affairs', No. 3, 20 Oct. 1945, 1 and table ii: Shortages of Medical Means, Military Government of United States Zone, 1 Oct. 1945, 10. The same number appears in BAK, 5/331-1/6 in a memorandum to Major General Stayer, 9 Oct. 1945.

‘Public Health and Medical Affairs’, No. 4, 20 Nov. 1945, 2.

49 'Public Health and Medical Affairs', No. 3, 20 Oct. 1945, 1.

50 'Public Health and Medical Affairs', No. 5, 20 Dec. 1945, 2.

51 Balfour, 'Four Power Control in Germany', in Balfour and Mair, Four Power Control in Germany and Austria, 104. Clay, Decision in Germany, 239-40.

52 e.g. BAK, Z45F, 44-45/1/6, notes on the Press Conference held on 30 Aug. 1945.

53 'Public Health and Medical Affairs', No. 1, 20 Aug. 1945, 1.

54 Military Government of Germany, 'Public Health and Medical Affairs: monthly report of military governor, U.S. Zone', No. 2, 20 Sept. 1945, 5 .

55 TNA, FO 371/46992, 'Denazification: Monthly Report of Military Governor, U.S. Zone', No. 3, 20 Oct. 1945, sent to the Foreign Office for information.

56 'Public Health and Medical Affairs', No. 1, 20 Aug. 1945, 1.

57 BAK, Z45F, 5/331-2/6, Adcock (HQ, USFET) to Director of Military Government Western Military District, 3 Oct. 1945.

58 BAK, Z45F, 5/331-2/6, Colonel W. L. Wilson (Chief, PHB, SHAEF) to PHWB, IA\&C, USGCC, subject: Information Concerning German Physicians in Official Capacity, 10 July 1945.

59 'Public Health and Medical Affairs', No. 1, 20 Aug. 1945, 1.

60 'Public Health and Medical Affairs', No. 2, 20 Sept. 1945, 1/2. 
61 'Public Health and Medical Affairs', No. 3, 20 Oct. 1945, 1.

62 e.g. BAK, Z45F, 5/331-2/6 (fiche 3), request for release of Dr Albrecht Borsche, 18 Dec. 1945. Borsche was a German POW held in a camp in Ostholstein.

63 BAK, Z45F, 5/331-2/6, Dr L. Schuchardt (German doctors' organization) to Colonel Litton (Darmstadt, OMGUS), 14 Sept. 1945. Their translation.

64 BAK, Z45F, 15/108-1/48, 'The German View: a report for counter-intelligence', HQ USFET, Military Intelligence Service Centre, 19 Nov. 1945.

65 BAK, Z45F, 5/331-1/6, 2 Oct. 1945, on the lack of civilian qualified health officers.

66 BAK, Z45F, 5/331-1/6, Major General M. C. Stayer (Chief, Public Health Branch) to the Denazification Policy Board, 21 Dec. 1945.

67 TNA, FO 1050/10, Chief of Staff, British Zone (Lt. Col. B. Robertson) to Under-Secretary of State for War (War Office, London), [Nov. 1945].

68 BAK, Z45F, 44-45/8/18, draft 'Policy regarding use of German technical specialists and government technicians who are in arrest categories', Major T. J. Bee, (Asst. Adjutant General) to Commanding General of USFET, 30 Aug. 1945.

69 BAK, Z45F, 5/331-2/6, Marvin Linick (PHO, 3rd Detachment, HQ) to GO 3rd Medical Group, subject: delicensing of Nazi medical personnel, 20 July 1945 . See also subsequent correspondence in this file.

70 e.g. Z45F, 5/331-2/6, Oscar A. Nelson (Captain MC, Public Health Officer) to The Office of AC of S, G2, Bremen Port Command, 17 Jan. 1946, discussed the case of Martin Schlütz: dismissed on 9 Nov. 1945 from his post as director of the homeopathic centre at the city hospital in Bremen because of his early entry (Apr. 1933) into the NSDAP, but was given a temporary licence and returned to his former position, 'The reason being that according to Subject, he could not be replaced.' On temporary licences, see Lt. Col. Philip D. Beckjord (Chief Public Health Branch) to Director (Denazification Division, Attention Major Darlock), 27 Aug. 1946.

71 'Public Health and Medical Affairs', No. 12, 20 July 1946, 2.

72 BAK, Z45F, 5/331-2/6, J. Pappas (Chief, Public Health Branch, IA\&C Division) to Director OMG Bavaria, 15 July 1946.

73 e.g. BAK, Z45F, 5/331-2/6, Byron Waksman (Captain, MC, Acting Chief Public Health \& Welfare Branch, OMG Bavaria) to OMGUS, Attention Colonel Wilson, 3 May 1946. BAB, DQ1/92, Kreisarzt in Memmingen to health office, 9 Jan. 1946-he quotes a directive from the Bavarian State Ministry of the Interior, according to which all non-Bavarian doctors who did not have a licence to practise in Bavaria on 1 Jan. 1939 were to be sent back home, or if they came from the newly annexed territories they were to go to Saxony or Thuringia in the Soviet Zone.

74 e.g. BAK, Z45F, 5/331-2/6, discussion of the case of Professor Schaupp, who was requested by the Medical Faculty of Tübingen University, 26 Oct. 1945, and following letters.

75 BAK, Z45F, 5/331-2/6, James P. Pappas (Chief, Public Health Branch) to District Public Health Officer (Western Military District), subject: Release of German Physician PW in British Camp, 13 Nov. 1945.

76 BAK, Z45F, 5/331-1/6, Dr L. Schuchardt (German doctors' organization) to Colonel Litton (Darmstadt, OMGUS), 14 September 1945. Their translation.

77 BAK, Z45F, 5/331-2/6, Howard Hansen (PHWB, USGCC, HQ) to Colonel Wilson (G5, USFET, PHW), 20 Sept. 1945. On Schaltenbrand see n. 78; on Tönnis, see Paul Weindling, 'Akteure in eigener Sache: Die Aussagen der Überlebenden und die Verfolgung der medizinischen Kriegsverbrechen nach 1945', in Carola Sachse (ed.), Die Verbindung nach Auschwitz: Wissenschaften und Menschenversuche an Kaiser Wilhelm-Instituten (Göttingen, 2004), 255-84.

78 Weindling, Nazi Medicine, 188-9; and Paul Weindling, “'Out of the Ghetto": The Rockefeller Foundation Confronts German Medical Sciences after the Second World War', in William H. Schneider (ed.), The Rockefeller Foundation and Biomedicine: International Achievements and Frustrations from World War I to the Cold War (Bloomington, Ind., 2002), 208-22. Ernst Klee, Deutsche Medizin im Dritten Reich: Karrieren vor und nach 1945 (Frankfurt, 2001). Schaltenbrand categorically denied the criminality of medical experiments conducted during the Nazi years, see W. Villinger and G. Schaltenbrand, 'Erklärung', Der Nervenarzt, 24/11 (July 1953), $362-4$.

79 TNA, FD1/2483, E. B. Strauss, 'Observations and Suggestions: Report on his visit to certain Universities in the American and French Zones, August 1946, by E. B. Strauss, M.A., D.M. (Oxon.), F.R.C.P.' [Aug. 1946]. 
80 Georg Schaltenbrand, Neurology: FIAT Review of German Science, 1939-1946, Account of Investigations and Advances Made by German Scientists (Office of Military Government for Germany, FIAT, Wiesbaden, 1948), pts. 1-3. Georg Schaltenbrand (ed.), Naturforschung und Medizin in Deutschland 1939-1946, für Deutschland bestimmte Ausgabe der FIAT Review of German Science, Vol.80-82: Neurologie (Wiesbaden, 1948).

81 BAK, Z45F, 5/331-2/6, G. H. Garde (Adjutant General) to Director, Public Health Branch, IA\&C Div, Zonal Executive Offices, CCG, Bünde, 20 Nov. 1946. Bishop of Chichester reference for Prof. Carl von Hindelang, 20 May 1946. Gwendoline Hill (Advisory Officer Save the Children Fund) to Major Ledbury (Zonal Executive Offices, IA\&C Division, 62 HQ CCG), 16 Sept. 1946. The material on Hindelang was sent from British Public Health and Welfare Branch to the Director, OMG Bavaria (Attention Senior Public Health Officer) on 15 Oct. 1946.

82 BAK, Z45F, 5/331-2/6, Paul Dudley White (Massachusetts General Hospital), to ETO surgeon, 26 Apr. 1946.

83 BAK, Z45F, 5/331-2/6, H. T. Marshall (Deputy Chief, PH\&WB) to Paul Dudley White, 9 Sept. 1946.

84 BAK, Z45F, 5/331-2/6, Ross Jenney (Chief, PHB, OMG Bavaria) to Paul Dudley White, 28 Jan. 1948.

85 BAK, Z45F, 5/331-2/6, Milford Kubin to Paul Dudley White, 10 Feb. 1948.

86 BAK, Z45F, 5/331-2/6, James Kind (Staff Secretary Berlin) to Dr Rudolf Thiel (Director of University Eye Clinic, Frankfurt), 11 Dec. 1947.

87 Dwight D. Eisenhower, Crusade in Europe (London, 1948), 480.

88 e.g. Lucius Clay to John McCloy, 3 Sept. 1945, repr. inJean Edward Smith (ed.), The Papers of General Lucius D. Clay (Bloomington, Ind., 1974), i. 66.

89 BAK, Z45F, 44-45/4/6, Eisenhower 'To all members of the United States Forces in the European Theater of Operations', [undated].

90 Donna Alvah, Unofficial Ambassadors: American Military Families Overseas and the Cold War, 1946-1965 (New York, 2007$), 133$.

91 BAK, Z45F, 44-45/8/18, Col. Bruce Easley (Adjutant General) to directors of divisions, Staff Officers and chiefs of separate sections, 6 Sept. 1945.

92 BAK, Z45F, 44-45/8/18, USFET (Bruce Easley, Office of the Deputy Military Governor) to Commanding General, US HQ Berlin District, 23 Sept. 1945.

93 BAK, Z45F, 15/109-1/48, 'The German View: a report for counter-intelligence', from HQ, USFET, Military Intelligence Service Center, 19 Nov. 1945.

94 Reference to the old American aristocracy, who did not understand 'democracy' and were thus ill-placed to teach it to foreigners. From John Collins Bossidy's poem from 1910, entitled 'Toast, Holy Cross Alumni Dinner': 'And this is good old Boston, The home of the bean and the cod, Where the Lowells talk to the Cabots, And the Cabots talk only to God.'

95 BAK, Z45F, 3/177-2/4, Joan S. Crane, 'Malice in Blunderland', undated [Apr. 1947].

96 BAK, Z45F, 3/177-2/4, Martin Sommers (Foreign Editor, Editorial Room, Saturday Evening Post) to Col. F. V. FitzGerald, 9 Apr. 1947.

97 e.g. 'An army wife lives very soft—in Germany. By Mrs Lelah Berry, as told to Ann Stringer', Saturday Evening Post, 15 Feb. 1947. On Patterson's, Clay's and other OMGUS officials' views of this article, see correspondence in BAK, Z45F, 3/177-2/4, Feb.-Mar. 1947.

98 BAK, Z45F, 5/331-2/6, Dr Gerlach (Public Health Commissioner), 26 Aug. 1946.

99 Standifer, Not in Vain, 240.

100 BAK, Z45F, 5/331-2/6, Minute from Philip Beckjord (Public Health Branch), to Director, Denazification Division (Attention Major Darlock), 27 Aug. 1946.

101 TNA, FO 371/46992, ‘Monthly Report of Military Governor, U.S. Zone’, No. 3, 20 Oct. 1945.

102 TNA, FO 371/46992, 'Denazification: monthly report of the Military Governor, U.S. Zone', No. 3, 20 Oct. 1945.

103 William E. Griffith, 'Denazification', 75.

104 BAK, Z45F, 5/332-1/20, Milford Kubin (IA\&C Div, PH\&W Branch), 'Revision of Military Government Plans and Operations 
necessitated by adoption of German Land constitutions and Bi-Zonal agreement with British Military Government', 29 Nov. 1946. For earlier, similar statements, see BAK, Z45F, 3/169-2/159, 'Minutes of the Meeting convened by Chief, Public Health Branch, G5 Division, SHAEF, for discussion of military government public health plans and operations', 15-16 Jan. 1945.

105 This is commented upon in LAB, B Rep. 012/902/5, 'Besprechung der Amtsärzte am Donnerstag, d.23.5.1946'.

106 OMGUS Report No. 94 (24 Feb. 1948), ‘Contacts between Germans and Americans', in Anna J. Merrit and Richard L. Merrit, Public Opinion in Occupied Germany: The OMGUS Surveys, 1945-1949 (Urbana, Ill., 1970), 202-3, also 10.

107 OMGUS Report No. 22 (25 Sept. 1946), ‘A Study of Attitudes Toward the Reconstruction and Rehabilitation of Germany', in Merritt and Merritt, Public Opinion, 103-6.

108 OMGUS Report No. 76 (29 Oct. 1947), 'German attitudes toward the four occupying powers', in Merritt and Merritt, Public Opinion, $180-1$.

109 LAB, B Rep. 012/902-5, ‘Amtsarztsitzung vom 12. Juli 1945, 16 Uhr-Versammlung der Amtsärzte am 12. Juli im Hauptgesundheitsamt.'

110 LAB, B Rep. 012/902-5, 'Bericht über die Dienstbesprechung der Amtsärzte am Donnerstag, dem 23. August 1945 [2nd draft]. Original emphasis.

111 e.g. statements by Colonel Pigarev and Colonel Prokopets, LAB, B Rep. 012/902-5, 'Bericht über die Dienstbesprechung am Donnerstag, dem 4. Oktober 1945', 4 Oct. 1945.

112 Heide Fehrenbach, Race after Hitler: Black Occupation Children in Postwar Germany and America (Princeton, 2007$), 29$.

113 e.g. Report No. 64 (25 Aug. 1947), 'Trends in Attitudes Toward the Food Situation', in Merritt and Merritt, Public Opinion, 167-70.

114 Compare with Dagmar Ellerbrock, 'Die kulturelle Konstruktion der neuen Ordnung: zum Zusammenhang von Demokratisierung und Gesundheitspolitik in der amerikanischen Besatzungszone', in Christian Groh (ed.), Öffentliche Ordnung in der Nachkriegszeit (Ubstadt-Weiher, 2002), 122.

115 Lucius Clay, 'Memorandum: Internationalisation of the Ruhr', Apr. 1946, repr. in Jean Edward Smith (ed.), The Papers of General Lucius Clay: Germany 1945-1949 (Bloomington, Ind., 1974), i. 196.

116 Clay, Decision in Germany, 281.

117 There is a large literature on food policy in post-war Germany, and its complex development can only be touched on here. An interesting discussion of the arguments used by Clay are presented in Günter Trittel, Hunger und Politik: Die Ernährungskrise in der Bizone, 1945-1949 (Frankfurt, 1990). Also see Michael Wildt, Der Traum vom Stattwerden: Hunger und Protest, Schwarzmarkt und Selbsthilfe (Hamburg, 1986). John Farquharson, Landwirtschaft und Ernährung in der Bizone, 1945-1949 (Frankfurt, 1990).

118 'Public Health and Medical Affairs', No. 3, 20 Oct. 1945. 'Public Health and Medical Affairs', No. 4, 20 Nov. 1945.

119 'Public Health and Medical Affairs', No. 5, 20 Dec. 1945. On the popularity of penicillin in VD treatment, see LAB, B Rep. 012/9025, 'Besprechung der Amtsärzte am Donnerstag, d.23.5.1946'.

120 'Public Health and Medical Affairs', No. 6, 20 Jan. 1946. But see Leiby on controversies surrounding the use of penicillin among the German population in the American zone, Richard Leiby, Public Health in Occupied Germany, 1945-1949 (PhD University of Delaware, 1984), 157-9. Because of disputes, penicillin shipments were temporarily interrupted between Nov. 1946 and Jan. 1947.

121 'Public Health and Medical Affairs', No. 7, 20 Feb. 1946. On the western sectors of Berlin, see LAB, B Rep. 012/902-27, LGA report for Apr. 1947 by epidemic department, 5 May 1947, on meetings of the penicillin committee. Also see Timm, The Politics of Fertility, 222.

122 BAK, Z45F, 5/331-3/10, Office of Military Government, Land Wuerttemberg-Baden, Public Health Conference in Berlin, 9 Sept. 1947.

123 Lucius Clay to John McCloy, 3 Sept. 1945, repr. in Smith (ed.), Papers of Lucius Clay, i. 66.

124 Lucius Clay to John McCloy, 16 Sept. 1945, repr. in Smith (ed.), Papers of Clay, i. 76-7.

125 Wolfgang Benz, Potsdam 1945: Besatzungsherrschaft und Neuaufbau im Vier-Zonen-Deutschland (1986; 3rd edn. Munich, 1994), 130.

126 'Public Health and Medical Affairs', No. 6, 20 Jan. 1946, 2. 
127 e.g. BAK, Z45F, 5/331-3/10, agenda for meeting on 8 July 1946 to review public health operations in the month of June 1946,26 June 1946 - anticipated the impending 'shifting of responsibility for [disease] reporting to the German authorities'.

128 'Public Health and Medical Affairs', No. 6, 20 Jan. 1946, 2.

129 Clay, Decision in Germany, 273.

130 TNA, FO 1032/1495, 'Confidential Report on Joint Meeting of Representatives of the Zonal Advisory Council and the Regional Government Co-Ordinating Office (Länderrat) at Stuttgart on April 3rd, 1946', 16 Apr. 1946. Also in Ralph Uhlig (ed.), Confidential Reports des Britischen Verbindungsstabes zum Zonenbeirat der britischen Besatzungszone in Hamburg, 1946-1948Demokratisierung aus britischer Sicht (Frankfurt, 1993), 59.

131 BAK, ZAF, 5/331-3/10, 'Public Health Conference' in Berlin on 9 Sept. 1947, OMG Land Wuerttemberg-Baden, 15 Sept. 1947.

132 On health policy discussions in the German Länderrat of the American zone, see Lia Härtel (ed.), Der Länderrat des Amerikanischen Besatzungsgebietes (Stuttgart, 1951). Antje Mohr, Hessen und der Länderrat des Amerikanischen Besatzungsgebietes (Frankfurt, 1999).

133 On tuberculosis in the American zone, see Ellerbrock, 'Die kulturelle Konstruktion der neuen Ordnung', 109-25. Dagmar Ellerbrock, 'Gesundheitspolitik in der amerikanischen Besatzungszone, 1945-1949', in Wolfgang Woelk and Jörg Vögele (eds.), Geschichte der Gesundheitspolitik in Deutschland: von der Weimarer Republik bis in die Frühgeschichte der 'doppelten Staatsgründung' (Berlin, 2002).

134 Esmond R. Long and Seymor Jablon, Tuberculosis in the Army of the United States in World War II: An Epidemiological Study with an Evaluation of X-ray Screening (Washington DC, 1955). Esmond R. Long, 'A Pathologists' Recollection of the Control of Tuberculosis', Perspectives in Biology and Medicine, 5 (1961-2), 24-51 [PubMed: 14466455]. George Washington Corner, 'Esmond R. Long (1890-1979): President of the American Association for the History of Medicine (1940-1941), a Memoir by his Long-Time Friend and Colleague Dr George W. Corner', Bulletin of the History of Medicine, 54 (1980), 273-4. Other members of the commission included Philip E. Sartwell, Colonel Silas B. Hays, and Major Alonzo W. Clark.

135 Office of Military Government for Germany (US), 'Tuberculosis - special report of the Military Governor, US Zone, Germany, adapted for publication by the civil administration division from a report rendered 5 March 1948 by a commission appointed by the Secretary of the Army', May 1948, 18.

136 See e.g. Jeffry Diefendorf, Axel Frohn, and Hermann-Joseph Rupieger (eds.), American Policy and the Reconstruction of West Germany (Cambridge, 2008). Hans-Jürgen Schröder, Marshallplan und westdeutscher Wiederaufstieg_Positionen, Kontroversen (Stuttgart, 1990). Donald Bloxham, 'The Genocidal Past in Western Germany and the Experience of Occupation, 1945-1946', European History Quarterly, 34/3 (2004), 305-3510.1177/0265691404044141 [CrossRef].

137 Press release on JCS 1779, 15 July 1947, quoted in Axel Lehman, Der Marshall-Plan und das neue Deutschland: Die Folgen amerikanischer Besatzungspolitik in den Westzonen (Münster, 2000), 99.

138 US Department of State, Office of Public Affairs, Current Problems in the Occupation of Germany: A Fact Sheet, June $1950,5$.

139 Robert Engler 'Individual Soldier', 84, 85.

140 Ellerbrock, 'Die kulturelle Konstruktion der neuen Ordnung', 121.

\section{(C) Jessica Reinisch 2013.}

This is an open access publication. Except where otherwise noted, this work is distributed under the terms of a Creative Commons AttributionNonCommercial- NoDerivatives 4.0 International licence (CC BY-NC-ND), a copy of which is available at http://creativecommons.org/licenses/by-ncnd/4.o/ Enquiries concerning use outside the scope of the licence terms should be sent to the Rights Department, Oxford University Press, at the above address.

Monographs, or book chapters, which are outputs of Wellcome Trust funding have been made freely available as part of the Wellcome Trust's open access policy

Bookshelf ID: NBK293866 